\title{
Integrated Weed Management in Wheat under Subtropical Rain-Fed Conditions
}

\author{
Muhammad Jamal Khan ${ }^{*}$, Muhammad Azim Malik ${ }^{1}$, Muhammad Ansar ${ }^{1}$, \\ Rahmatullah Quershi ${ }^{2}$ and Graham lan Brodie ${ }^{3}$
}

${ }^{1}$ Department of Agronomy, Pir Mehr Ali Shah-Arid Agriculture University Rawalpindi, Pakistan

${ }^{2}$ Department of Botany, Pir Mehr Ali Shah-Arid Agriculture University Rawalpindi, Pakistan

${ }^{3}$ Faculty of Veterinary and Agricultural Sciences, The University of Melbourne, Victoria, 3647, Australia

\begin{abstract}
A field experiment was carried out from July, 2013 to May, 2014 at University Research Farm Chakwal Road, of Pir Mehr Ali Shah-Arid Agriculture University, Rawalpindi to evaluate the integrated weed control management strategies followed by summer green manure practices on weeds and grain yield of wheat under rain-fed conditions. The experiment was laid out in a 2-factor factorial Randomized Complete Block Design (RCBD) in strip plot arrangement with three replications of each treatment. The sorghum and sesbania crops were sown in the first week of July, 2013 and incorporated into soil as green manure at the end of August, 2013 after attaining sufficient biomass. The wheat variety "Chakwal-50" was sown with a tractor drawn rabi drill in the last week of October, 2013 with a seeding rate of $125 \mathrm{~kg}$ ha $^{-1}$. The herbicides used were buctril super @ 750 $\mathrm{ml} \mathrm{ha}^{-1}$ and isoproturon @ 1.00kg a.i. ha ${ }^{-1}$. The weeds found in the wheat crop were Fumaria indica L., Convolvulus arvensis L., Chenonpodium album L., Asphodelus tenuifolius L. The incorporation of sorghum green manuring resulted in good control to suppress the weed population and biomass. The buctril super @ $750 \mathrm{ml} \mathrm{ha}^{-1}$ along with tharphali significantly reduced the weed density $\left(18.8 \mathrm{~m}^{-2}\right)$, weed biomass $(12.7 \mathrm{~g}$ $\mathrm{m}^{-2}$ ) and increased weed control efficiency $(71.1 \%)$ followed by isoproturon applied @ $1.00 \mathrm{~kg}$ a.i. ha ${ }^{-1}$. The highest grains yield of $3208.5 \mathrm{~kg} \mathrm{ha}^{-1}$ was recorded in the plots where weeds were controlled with buctril super @ 750 $\mathrm{ml} \mathrm{ha}^{-1}$ followed by tharphali where sorghum green manure was incorporated in summer followed by the isoproturon application @ 1.00kg a.i. $\mathrm{ha}^{-1}\left(3016.1 \mathrm{~kg} \mathrm{ha}^{-1}\right)$ in combination with tharphali in the same green manuring crop.
\end{abstract}

Keywords: Integrated weed management, weeds, green manuring, herbicides, wheat (Triticum asetivum L.).

\section{INTRODUCTION}

Wheat (Triticum aestivum L.) is one of the most important cereals and is produced all over the world. It is the prominent staple food and the leading grain crop of Pakistan and sufficiently feeds the masses in the country. It is grown on areas of 9.06 million ha with total production of about 25 million tons. Wheat average yield is approximately $2.83 \mathrm{t} \mathrm{ha}^{-1}$. However, in rain-fed conditions, the total cultivated area of wheat crop is around 1.24 million ha with the crop yield of 1.94 million tons and the average yield of almost $1.53 \mathrm{t}$ $\mathrm{ha}^{-1}$. In spite of the combined struggles of researchers and farmers, these yields are still failing to achieve the potential yield of wheat crops (i.e. $6 \mathrm{t} \mathrm{ha}^{-1}$ ).

Weed infestation is a serious problem affecting the yield of wheat. The statistical range of wheat yield reduction in Pakistan caused by weeds is about 20 $30 \%$ [1]. Weeds are the foremost barrier in the production of wheat as they decrease the crop productivity by competing for soil moisture, nutrients, light, and $\mathrm{CO}_{2}$. They exude allelopathic chemicals in the soil; provide environments for disease causing

*Address correspondence to this author at the Dookie Campus the University of Melbourne, Dookie Victoria 3647, Australia; Tel: 0469601305; Fax: +61 35833 9201; E-mail: mkhan3@student.unimelb.edu.au agents along with the allocation of substitute host for several insects; and increase the cost of harvesting [2]. Weeds are responsible for declining crop yield, not only through competing for essential limiting factors of plant growth and development, but also through the release of certain allelochemicals from the root system and other parts of plants into the root zone of desired crop plants.

Incorporation of green manure residues into the soil has a significant influence on the weed's life span by reducing weed seed germination, and restricting growth and development of individual weed species [3]. Herbicides successfully control weeds and improve the grain yield of crops [4-6]. In cropping system it is very effective method of weed control as it minimizes the crop productivity losses due to weed invasion and reduces the subsequent infestation of weeds at low and persistent levels.

Integrated weed management (IWM) is a policymaking process based on the basic principles of science that bring together the information of climate, weed life span i.e. seeds, newly emerged plant, vegetative growth stages, flowering and seed set, and their relationship to the environment and all accessible approaches for weed management by the most costeffective and environmentally sustainable methods [7]. 
IWM is a multiple-approached weed control strategy to minimize the weed population. This concept includes various weed control methods such as herbicides, conservation and conventional tillage systems, crop rotation, crop topping, incorporation of green manure crops into the soil, seed capture at harvest, flaming and grazing. IWM would reduce herbicide resistance in weed species on long-term coverage [8]. IWM may be responsible for a more workable system of weed control [9]. Green manuring can retard weed germination in soils through effects on the radiation and chemical composition of the seed. Sarrantonio and Gallandt [10] reported that when fresh residue is incorporated into soil, the decomposition process can release phytotoxins that inhibit germination and early growth of weeds. The incorporation of green manures significantly affected the weed life cycle [11]. The allelopathic green manuring crops released allelochemicals of different chemistry that suppressed the weeds in subsequent crops. Along with the allelopathic effect the green manure, crop residues also retard weed seed emergence and growth by other mechanisms.

Keeping in view the importance of wheat and weed associated problems this study ought to be considered an essential component of integrated weed management. The objectives of the study were; to evaluate the impact of integrated weed control practices for suppressing weeds in wheat crop and to improve wheat grain yield within green manuring option under rainfed conditions.

\section{MATERIAL AND METHODS}

A field experiment was conducted to evaluate the multi-approached weed control methods in wheat with the objective to investigate the effect of different green manuring and application of herbicides on weeds in a wheat crop under rainfed conditions. The experiment was carried out at the University Research Farm,

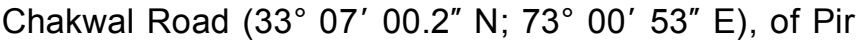
Mehr Ali Shah-Arid Agriculture University, Rawalpindi during July, 2013 - May, 2014. The experiment was laid out in 2 factor factorial Randomized Complete Block Design (RCBD) in strip plot arrangement with three replications of each treatment. The plot size was $2 \times 3$ $\mathrm{m}$. The sorghum green manuring crop was sown at $75 \mathrm{~kg} \mathrm{ha}^{-1}$ and the sesbania was sown at $45 \mathrm{~kg} \mathrm{ha}^{-1}$ in the first week of July, 2013 and incorporated into the soil with the help of disc harrow and rotavator in late August, 2013. The wheat variety Chakwal-50 was sown by using the recommended seed rate of $125 \mathrm{~kg} \mathrm{ha}^{-1}$ with the help of Rabi drill in the last week of October,
2013. The fertilizers NPK were applied at the time of sowing at $90-60-60 \mathrm{~kg} \mathrm{ha}^{-1}$ as a basal dose, respectively. All the cultural practices were followed according to the recommendations. Treatments were: Green manuring: $\mathrm{GM}_{1}=$ Without Green Manuring, $\mathrm{GM}_{2}=$ Sorghum (Sorghum bicolor L.), $\mathrm{GM}_{3}=$ Sesbania (Sesbania rostrata L.), While winter weed control methods: $\mathrm{WCM}_{1}$ : Weedy Check (Control), $\mathrm{WCM}_{2}$ : Hand Hoeing, $\mathrm{WCM}_{3}$ : Buctril Super @ 750ml ha ${ }^{-1}, \mathrm{WCM}_{4}$ : Isoproturon 50WP @ $1.00 \mathrm{~kg}$ a.i. ha ${ }^{-1}, W^{-1} M_{5}$ : Tharphali, $\mathrm{WCM}_{6}$ : Tharphali + Buctril Super @ 750ml ha $^{-1}, W^{-1} M_{7}$ : Tharphali + Isoproturon 50WP @ 1.00kg a.i. ha ${ }^{-1}$.

\subsection{Plant Biometrical Measurement}

Weed population was recorded using a quadrate of one meter square, taking two samples from each plot before and after application of treatments and at wheat harvest; the average was determined. Weed biomass was taken at harvesting time and was placed in an oven at $65^{\circ} \mathrm{C}$ for 48 hours and dry matter weight was recorded. Fresh biomass of weed was taken out from treated and untreated plot and was dried at $65^{\circ} \mathrm{C}$ using an oven. Dry matter and weed control efficiency was calculated using the following formula.

$W C E(\%)=\frac{D M W u t-D M W t}{D M W u t} \times 100$

Where:

DMWut= Dry matter of weed from un-treated plots

$\mathrm{DMWt}=$ Dry matter of weed from treated plots

The spike length was recorded in centimeters starting from the base to the end of the spike, but not including awns, of 10 randomly selected spikes and the average was calculated. The spikelets per spike were recorded by taking a sample of ten spikes. The average value was calculated. The grains per spike were determined by counting the grains of ten randomly selected spikes and their average value was calculated for analysis. For measuring the 1000-grains weight, three samples from the produce of each experimental plot were recorded. The samples were weighed in grams and the average was calculated. At maturity each plot was harvested, weighed for biological yield, and after threshing total yield per plot was recorded and calculated. The statistical analysis of mean data was done by using the software STATISTIX 8.1. The meteorological data of experimental site are given in Table 1. The least significant difference (LSD) 
Table 1: Meteorological Data (Temperature and Average Rainfall) of Chakwal During the Growth Period of Wheat

\begin{tabular}{|c|c|c|c|c|}
\hline \multirow{2}{*}{ Months } & \multicolumn{3}{|c|}{ Temperature ${ }^{\circ} \mathbf{C}$ ) } & \multirow{2}{*}{ Rainfall (mm) } \\
\cline { 2 - 5 } & Maximum & Minimum & Average & 24.6 \\
\hline \hline October, 13 & 32.29 & 18.35 & 15.57 & 14.3 \\
\hline November, 13 & 23.49 & 7.65 & 11.58 & 4.3 \\
\hline December, 13 & 20.40 & 2.75 & 14.94 & 0.0 \\
\hline January, 14 & 23.42 & 6.45 & 12.29 & 37.4 \\
\hline February, 14 & 18.22 & 6.35 & 14.43 & 94.1 \\
\hline March, 14 & 19.70 & 9.16 & 20.79 & 66.0 \\
\hline April, 14 & 25.48 & 16.10 & 24.62 & 67.5 \\
\hline May, 14 & 26.11 & 23.13 & & 308.2 \\
\hline
\end{tabular}

test at 0.05 probability levels to compared the difference among treatments means.

\section{RESULTS AND DISCUSSIONS}

\subsection{Effect of Various Treatments on Weed Growth}

\subsubsection{Weed Density $\left(m^{-2}\right)$}

The existing weed species of the experimental area were Fumaria indica L., Convolvulus arvensis L., Chenonpodium album L., Asphodelus tenuifolius L. Statistical analysis of data, as presented in Table 2, illustrated that there was a significant effect of sorghum and sesbania green manures and different weed control methods on weed density in wheat. The green manuring effect was statistically significant to reduce the weed density when compared with plots where no green manuring was practiced.

The minimum weed density of $39.0 \mathrm{~m}^{-2}$ was recorded in the case of sorghum green manuring and it was similar to the sesbania green manuring, which had a weed density of $40.5 \mathrm{~m}^{-2}$. The decline in weed population may be due to the allelopathic effect of preflowering incorporation of sorghum green manuring. The maximum weed density of $46.5 \mathrm{~m}^{-2}$ was recorded in the green manure free plot.

Similarly, the weed control methods have significant effect on the weed population of prevailing weed species in wheat. The lowest weed density of $18.8 \mathrm{~m}^{-2}$ was found in plots $\left(\mathrm{WCM}_{6}\right)$ (buctril super @ $750 \mathrm{ml} \mathrm{ha}^{-1}$ + tharphali) followed by the $\mathrm{WCM}_{7}$ (Isoproturon @

Table 2: Effect of Green Manuring and Weed Control Methods on Weed Density, Weed Dry Weight and Weed Control Efficiency

\begin{tabular}{|c|c|c|c|}
\hline Treatments & Weed Density $\left(\mathrm{m}^{-2}\right)$ & Weed Biomass $\left(\mathrm{g} \mathrm{m}^{-2}\right)$ & Weed Control Efficiency (\%) \\
\hline \multicolumn{4}{|l|}{ Green Manuring } \\
\hline $\mathrm{GM}_{1}$ & $46.5 a$ & $23.7 a$ & $48.2 c^{*}$ \\
\hline $\mathrm{GM}_{2}$ & $39.0 b$ & $17.4 \mathrm{c}$ & $57.7 a$ \\
\hline $\mathrm{GM}_{3}$ & $40.5 b$ & $19.8 b$ & $52.1 b$ \\
\hline \multicolumn{4}{|c|}{ Weed Control Methods } \\
\hline $\mathrm{WCM}_{1}$ & $19.2 a$ & $40.7 a$ & $0.0 \mathrm{~m}$ \\
\hline $\mathrm{WCM}_{2}$ & $42.0 c$ & $21.4 b$ & $51.2 d$ \\
\hline $\mathrm{WCM}_{3}$ & $22.1 d$ & $14.3 d$ & $67.4 \mathrm{~b}$ \\
\hline $\mathrm{WCM}_{4}$ & $23.8 d$ & $16.1 \mathrm{c}$ & $63.2 c$ \\
\hline $\mathrm{WCM}_{5}$ & $46.7 b$ & $21.9 b$ & $50.2 d$ \\
\hline $\mathrm{WCM}_{6}$ & $18.8 \mathrm{e}$ & $12.7 e$ & $71.1 \mathrm{a}$ \\
\hline $\mathrm{WCM}_{7}$ & $21.4 \mathrm{de}$ & $15.1 \mathrm{~cd}$ & $65.4 \mathrm{bc}$ \\
\hline
\end{tabular}

*Any two means not shearing a letter in common in column and row differ significantly at $5 \%$ probability level.

Where: $\mathrm{GM}_{1}=$ Without green manurimg, $\mathrm{GM}_{2}=$ Sorghum, $\mathrm{GM}_{3}=$ Sesbania, $\mathrm{WCM}_{1}=$ Control, $\mathrm{WCM}_{2}=$ Hand hoeing, WCM $=\mathrm{Buctril}_{3}$ 
$1.00 \mathrm{~kg}$ a.i. $\mathrm{ha}^{-1}+$ tharphali) with a recorded weed density of $21.4 \mathrm{~m}^{-2}$. Both of the weed control methods $\left(\mathrm{WCM}_{6}\right.$ and $\left.\mathrm{WCM}_{7}\right)$ were statistically similar to each other, but significantly differed from the rest of the weed control methods. The application of buctril super $@ 750 \mathrm{ml} \mathrm{ha}^{-1}$ showed better performance at suppressing the weed density $\left(22.1 \mathrm{~m}^{-2}\right)$. The $76 \%$ decrease in the weed density with applications of buctril super was reported by Sharif et al. [12]. The maximum weed density of $119.2 \mathrm{~m}^{-2}$ was noted in the $\mathrm{WCM}_{1}$.

The reason of reduced weed density in wheat was probably due to decomposition of green manure residues which released the phytotoxins and thus significantly inhibited the weed seed germination and growth. Similar results have been reported by Sarrantonio and Gallandt [10]. The findings are in correspondence with the study of Teasdale and Mohler [13], who described that weed seed emergence, is physically hindered by green manure residues. The results are in accordance with the work of Cheema and Khaliq [14], who also recorded concluded that $40.8 \%$ decrease in weed density was recorded with the incorporation of sorghum live mulch for weed management in wheat. The results are correlated with the findings of Ashiq et al. [15], who reported that the weed density significantly decreased through the application of herbicides.

\subsubsection{Weed Biomass $\left(\mathrm{g} \mathrm{m}^{-2}\right)$}

The weed dry biomass accumulation is an applicable parameter for evaluating the antagonistic nature of weeds for resource utilization and to compete with crop plants. The weed biomass was significantly reduced by all the weed control methods followed after the incorporation of sorghum and sesbania green manuring (Table 2). The green manuring significantly decreased the dry matter production of weeds. The lowest weed biomass of $17.4 \mathrm{gm}^{-2}$ was recorded from the plots where sorghum green manure was practiced followed by the sesbania live mulch incorporation $\left(19.8 \mathrm{gm}^{-2}\right)$. The maximum weed biomass of $23.7 \mathrm{gm}^{-2}$ was noted in the green manure free plots.

The lowest weed dry weights, owing to release of phytotoxins during decomposition of green manure crops, supressed the weeds. Similar results have been reported by Bhadoria [16]. The results are in accordance with the study of Czarnota et al. [17], who described that "Sorgoleone", an allelochemical release from the roots of sorghum, sufficiently retards weed growth and ultimately reduced the weed dry biomass.
Similarly, all the weed control methods affected the weed dry biomass. The minimum weed dry matter of $12.7 \mathrm{~g} \mathrm{~m}^{-2}$ was recorded in plots where $\mathrm{WCM}_{6}$ followed by the $W_{C M}$ and $W_{C M}$ with weed dry biomass of $14.3 \mathrm{~g} \mathrm{~m}^{-2}$ and $15.1 \mathrm{~g} \mathrm{~m}^{-2}$, respectively. These weed control methods $\left(\mathrm{WCM}_{6}, \mathrm{WCM}_{3}\right.$ and $\left.\mathrm{WCM}_{7}\right)$ were statistically similar to each other, but differed significantly compared to other weed control methods. The maximum decline in weed dry biomass was attributed to the application of post emergence herbicides. The results are in agreement with the findings of Zahoor et al. [18], who reported that the application of buctril super significantly reduced the weed dry weight. The highest weed biomass of $40.7 \mathrm{~g} \mathrm{~m}^{-2}$ was obtained in the weedy check plots $\left(\mathrm{WCM}_{1}\right)$.

The results are in line with the study of Amare et al. [19], who reported that application of isoproturon @ $1.00 \mathrm{~kg} \mathrm{ha}^{-1}$ significantly reduced the weed dry weight in wheat. The findings of this study are correlated with the work of Creamer and Baldwin [20], who reported $94 \%$ decline in weed biomass with sorghum green manuring grown for weed management compared to control without green manuring.

\subsubsection{Weed Control Efficiency (\%)}

The examination of data pertaining to weed control efficiency, presented in Table 2, showed statistically significant effect. The green manure grown as a part of integrated weed management represented a considerable increase in the weed control efficiency. The highest weed control efficiency of $57.7 \%$ was recorded from the plot where sorghum green manure was incorporated followed by the sesbania green manuring $(52.1 \%)$. The lowest weed control efficiency of $48.2 \%$ was recorded from green manure free plots.

Similarly, all the weed control methods showed significant difference in the weed control efficiency of various tested treatments in wheat. The highest weed control efficiency of $71.1 \%$ was recorded in $\mathrm{WCM}_{6}$ followed by the $\mathrm{WCM}_{3}(67.4 \%)$. Both of the weed control methods $\left(\mathrm{WCM}_{6}\right.$ and $\left.\mathrm{WCM}_{3}\right)$ were statistically similar to each other, but extensively differed from the rest of the weed control methods. The $\mathrm{WCM}_{7}(65.4 \%)$ showed better performance in response to weed control efficiency followed by the $\mathrm{WCM}_{4}(63.2 \%)$. The minimum weed control efficiency was measured in the $\mathrm{WCM}_{5}(50.2 \%)$.

The incorporation of sorghum green manure and the application of post emergence herbicides 
significantly reduced the weed dry weight, ultimately increases the weed control efficiency. The results are correlated with the study of Hossain et al. [21], who documented that application of post emergence herbicides reduced the weed dry weight and consequently drastically increased weed control efficiency in wheat. The results are in accordance with the work of Singh et al. [22] who reported that maximum weed control efficiency was obtained with the use of herbicides in wheat. The results are in agreement with the finding of Amare et al. [19] who reported that application of isoproturon @ 1.00kg a.i. $\mathrm{ha}^{-1}$ significantly reduced the weed dry biomass, which ultimately increased the weed control efficiency in wheat.

\subsection{Effect of Various Treatments on Yield and Yield Components of Wheat}

\subsubsection{Spike Length (cm)}

Spike length influenced the grains per spike and consequently affected the grains yield of the wheat crop. Statistical analysis of data showed that spike length of wheat was significantly affected by all the weed control measures fallowed after green manuring (Table 3).

The perusal of data on the effect of green manuring indicated that the highest spike length of $9.42 \mathrm{~cm}$ was noted in the experimental plots where the incorporation of sorghum green manure was done followed by sesbania green manuring, which resulted in the spike length of $9.40 \mathrm{~cm}$. The sorghum and sesbania green manuring were statistically similar to each other but differed significantly for the spike length of $8.35 \mathrm{~cm}$ from the green manuring free plots. This may be due to the incorporation of green manure residues, which physically and chemically supressed the weeds as reported by Xuan et al. [23], and contributes to more translocation of photosynathes and thus increased the spike length of wheat. Similar results have been reported by Borras et al. [24].

The examination of data showed that weed control methods significantly increased the spike length of wheat. The maximum spike length of $10.13 \mathrm{~cm}$ was measured from the experimental plots where buctril super @ $750 \mathrm{ml} \mathrm{ha}^{-1}\left(\mathrm{WCM}_{3}\right)$ was applied followed by weed control method which was the integration of buctril super @ 750ml ha ${ }^{-1}+$ tharphali $\left(\mathrm{WCM}_{7}\right)$, resulting spike length of $9.81 \mathrm{~cm}$. Both of the weed control methods were statistically similar to each other but varied significantly from rest of the weed control methods. The lowest spike length of $7.95 \mathrm{~cm}$ was recorded in the weedy check $\left(\mathrm{WCM}_{1}\right)$.

The combined effect of allelopathic residues and application of post emergence herbicides significantly reduced the weed infestation and in consequence produced less weed-crop competition for essential plants nutrients. The results are in line with the findings of Jabran et al. [25], who reported that application of buctril super @ 450g a.i. ha ${ }^{-1}$ considerably increased the spike length of wheat. The findings are in accordance with the work of [26], who concluded that longer spikes were produced in wheat by the application post-emergence herbicides. The results are also similar to the study by Cheema and Khaliq [14], who reported that the incorporation of sorghum significantly increased the spike length of wheat.

\subsubsection{Number of Spikelet Per Spike}

The perusal of data, presented in Table $\mathbf{3}$, showed the significant effect of green manuring and different weed control methods on the number of spikelets spike $^{-1}$ of wheat. The green manuring significantly increased the number of spikelets spike ${ }^{-1}$. The highest number of spikelets spike ${ }^{-1}$ of 16.14 was recorded in sesbania green manuring followed by sorghum green manuring (15.85). Both of the green manure treatments was statistically similar to each other but differed significantly from the green manure free plots (13.33). The increase in the number of spikelets spike ${ }^{-1}$ in sesbania green manuring may be due to more availability of nitrogen to wheat crop and resulting reduction in weed infestation. Similar results have been reported by Caamal-Maldonado et al. [27], who reported that legume green manures significantly reduced the weeds in subsequent cash crops.

The weed control methods significantly increased the number of spikelets spike ${ }^{-1}$ of wheat. The highest number of spikelets spike ${ }^{-1}$ of 17.23 was recorded from $\mathrm{WCM}_{3}$ followed by $\mathrm{WCM}_{6}$ (16.89). Both weed control methods $\left(\mathrm{WCM}_{3}\right.$ and $\left.\mathrm{WCM}_{6}\right)$ were statistically similar to each other but differed significantly from rest of the weed control methods. The lowest number of spikelets spike ${ }^{-1}$ of 12.66 was noted in the inter-hoeing $\left(\mathrm{WCM}_{5}\right)$ followed by the weedy check $\left(\mathrm{WCM}_{1}\right)$, resulting in 12.67 spikelets spike ${ }^{-1}$. The better performance of $\mathrm{WCM}_{3}$ and $\mathrm{WCM}_{6}$ as compared to other weed control methods could be probably owing to effective weed suppression responsible for good crop stand and thus increased in the number of spikelets spike ${ }^{-1}$. Similar results have been reported by Cheema et al. [14]. 
The application of herbicides significantly retards the weed growth and legumes green manure incorporation increased the nutrient availability for better crop production and ultimately resulted in increased number of spikelets spike ${ }^{-1}$. The findings are supported by the study of Hartwig and Ammon [28], who concluded legume cover crops have the potential to suppress the weed.

\subsubsection{Number of Grain Per Spike}

The effect of green manuring and different weed control methods on number of grains spike ${ }^{-1}$ was significant. The data pertaining to grains spike ${ }^{-1}$ are presented in Table 3 . The grains spike ${ }^{-1}$ was significantly affected by sorghum and sesbania green manuring. The maximum number of grains spike ${ }^{-1}$ of 41.95 was recorded from the experimental plots where sorghum green manuring was incorporated followed by sesbania green manuring with the grains spike ${ }^{-1}$ of 39.52 , both of the green manures were statistically similar to each other but differed significantly in the number of grains spike ${ }^{-1}$ (36.38) from plots without green manuring. This might be possibly due to soil incorporation of sorghum green manure successfully reduced the population and dry matter production of weeds and ultimately increased in the production of grains spike ${ }^{-1}$ in wheat. The results are correlated with study of Ahmad et al. [29].

Similarly, the number of grains spike ${ }^{-1}$ was affected by different weed control methods. The effect of all the weed control methods illustrated statistically significant differences for the number of grains spike ${ }^{-1}$. The maximum number of grains spike ${ }^{-1}$ (44.34) was recorded in $W_{C M}$ followed by $W_{C M}$ the resulted in grains spike ${ }^{-1}$ of 43.45 . These weed control methods were statistically similar to each other but differed significantly from all the weed control methods. The lowest number of grain per spike (29.11) was measured in the weedy check $\left(\mathrm{WCM}_{1}\right)$.

The increase in the number of grains spike ${ }^{-1}$ was possibly attributed to more weed suppression, which ultimately enhanced the translocation and accumulation of photosynathates to grain formation in the wheat [24]. These findings are in accordance with the study of lqbal [30], who reported an increase in the number of grains spike ${ }^{-1}$ with the application of board spectrum post emergence herbicides. The results are correlated with findings of Awan et al. [31], who reported that the allelopathic water extract of sorghum, used for weed suppression in wheat, significantly enhanced the grains spike ${ }^{-1}$.

\subsubsection{0-Grains Weight (g)}

Statistical analysis of data indicated that the 1000grain weight of wheat was significantly affected by all the weed control methods following the incorporation of sorghum and sesbania green manures (Table 3 ). The main effect of green manuring revealed that the maximum 1000 -grain weight of $41.70 \mathrm{~g}$ was achieved from the experimental plot where sorghum green

Table 3: Effect of Green Manuring and Weed Control Methods on Yield Components of Wheat

\begin{tabular}{|c|c|c|c|c|c|}
\hline Treatments & $\begin{array}{l}\text { Spike Length } \\
\text { (cm) }\end{array}$ & $\begin{array}{l}\text { No. of Spikelet } \\
\text { Spike }^{-1}\end{array}$ & $\begin{array}{l}\text { No. of Grain } \\
\text { Spike }^{-1}\end{array}$ & $\begin{array}{l}\text { 1000-Grain Weight } \\
\text { (g) }\end{array}$ & $\begin{array}{c}\text { Grain Yield } \\
\left(\mathrm{kg} \mathrm{ha}^{-1}\right)\end{array}$ \\
\hline \multicolumn{6}{|l|}{ Green Manuring } \\
\hline $\mathrm{GM}_{1}$ & $8.35 b$ & $13.33 b$ & $36.38 \mathrm{c}$ & $36.4 \mathrm{c}$ & $2381.6 c$ \\
\hline $\mathrm{GM}_{2}$ & $9.42 a$ & $15.85 a$ & $41.95 \mathrm{ba}$ & $41.7 a$ & $2944.3 a$ \\
\hline $\mathrm{GM}_{3}$ & $9.40 a$ & $16.14 a$ & $39.52 a$ & $39.7 b$ & $2735.9 b$ \\
\hline \multicolumn{6}{|c|}{ Weed Control Methods } \\
\hline $\mathrm{WCM}_{1}$ & $7.95 \mathrm{e}$ & $12.67 d$ & $29.11 \mathrm{e}$ & $31.3 d$ & $1835.3 e$ \\
\hline $\mathrm{WCM}_{2}$ & $9.01 b c$ & $14.65 \mathrm{c}$ & $38.11 \mathrm{c}$ & $36.4 \mathrm{c}$ & $2433.0 c$ \\
\hline $\mathrm{WCM}_{3}$ & $10.13 a$ & $17.23 a$ & $44.34 a$ & $42.6 b$ & $2963.6 b$ \\
\hline $\mathrm{WCM}_{4}$ & $8.71 \mathrm{~cd}$ & $15.77 \mathrm{bc}$ & $42.34 b$ & $41.5 b$ & $3016.1 b$ \\
\hline $\mathrm{WCM}_{5}$ & $8.47 d$ & $12.66 \mathrm{~d}$ & $34.67 d$ & $36.5 \mathrm{c}$ & $2154.7 d$ \\
\hline $\mathrm{WCM}_{6}$ & $9.81 \mathrm{a}$ & $16.89 a b$ & $43.00 \mathrm{ab}$ & $44.5 a$ & $3208.5 a$ \\
\hline $\mathrm{WCM}_{7}$ & $9.33 b$ & $15.88 \mathrm{bc}$ & $43.45 a b$ & $42.1 \mathrm{~b}$ & $3199.8 a$ \\
\hline
\end{tabular}

*Any two means not shearing a letter in common in column and row differ significantly at $5 \%$ probability level.

Where, $\mathrm{GM}_{1}=$ Without green manurimg, $\mathrm{GM}_{2}=$ Sorghum, $\mathrm{GM}_{3}=$ Sesbania, $\mathrm{WCM}_{1}=$ Control, $\mathrm{WCM}_{2}=\mathrm{Hand}_{\mathrm{C}}$ hoeing, $\mathrm{WCM}_{3}=\mathrm{Buctri}$ 
manure was incorporated followed by sesbania green manure with the obtained 1000 -grain weight of $39.76 \mathrm{~g}$. The minimum 1000-grain weight was attained from plot where no green manure was practiced.

Similarly, effects of all the weed control methods have significant effect on 1000-grain weight of wheat. The maximum 1000 -grain weight of $44.59 \mathrm{~g}$ was found in experimental plots where buctril super @ $750 \mathrm{ml} \mathrm{ha}^{-1}$ + tharphali $\left(\mathrm{WCM}_{6}\right)$ was applied followed by the sole application of buctril super @ $750 \mathrm{ml} \mathrm{ha}^{-1}\left(\mathrm{WCM}_{3}\right)$ the attained grain weight of $42.60 \mathrm{~g}$. These weed control methods were statistically similar to isoproturon @ $1.00 \mathrm{~kg}$ a.i. ha ${ }^{-1}+$ tharphali $\left(\mathrm{WCM}_{7}\right)$, with the resulting grain weight of $42.14 \mathrm{~g}$ and isoproturon @ $1.00 \mathrm{~kg}$ a.i. $\mathrm{ha}^{-1}\left(\mathrm{WCM}_{4}\right)$ with the grain weight of $41.56 \mathrm{~g}$. The minimum 1000 -grain weight of $31.31 \mathrm{~g}$ was measured in the weedy check $\left(\mathrm{WCM}_{1}\right)$ followed by the hand hoeing $\left(\mathrm{WCM}_{2}\right)$ which attained a grain weight of $36.44 \mathrm{~g}$.

The possible reason behind the highest 1000-grain weight might be that the decline in weed infestation provided suitable environmental conditions for crop growth and development. The results are consistent with findings of Cheema and Khaliq [32], who reported that 1000-grian weight was increased by sorghum stalk incorporation @ 6Mg ha ${ }^{-1}$ and by the applications of Bromoxynil + MCPA@1.2 L ha ${ }^{-1}$ and Isoproturon @ $2.0 \mathrm{~kg}$ a.i. ha ${ }^{-1}$. The results are also coordinated with the study of Mushtaq et al. [33], who documented that the 1000-grain weight was increased with the minimum weed invasion.

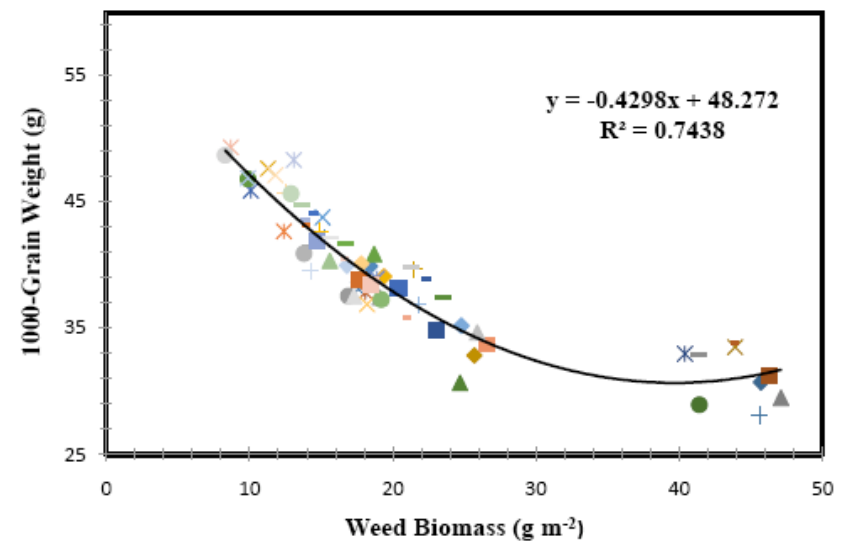

Figure 1: Relationship between 1000-grain weight and weed biomass.

\subsubsection{Grains Yield $\left(\mathrm{kg} \mathrm{ha}^{-1}\right)$}

Grain yield is a contribution of its yield related parameters particularly, 1000-grain weight. Furthermore, in rainfed area the grain yield of wheat is essentially dependent on the timely availability of soil moisture. The perusal of data Table 3 regarding grain yield collected in response to different weed control methods fallowed after the incorporation of sorghum and sesbania fresh residue depicted that all the weed management practices have significant effect on grain yield of wheat in both green manures.

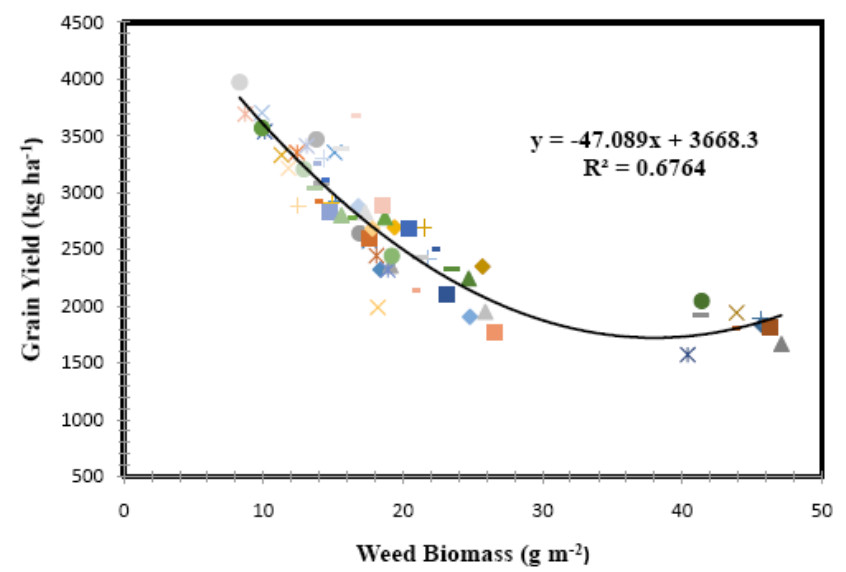

Figure 2: Relationship between grain yield weed biomass.

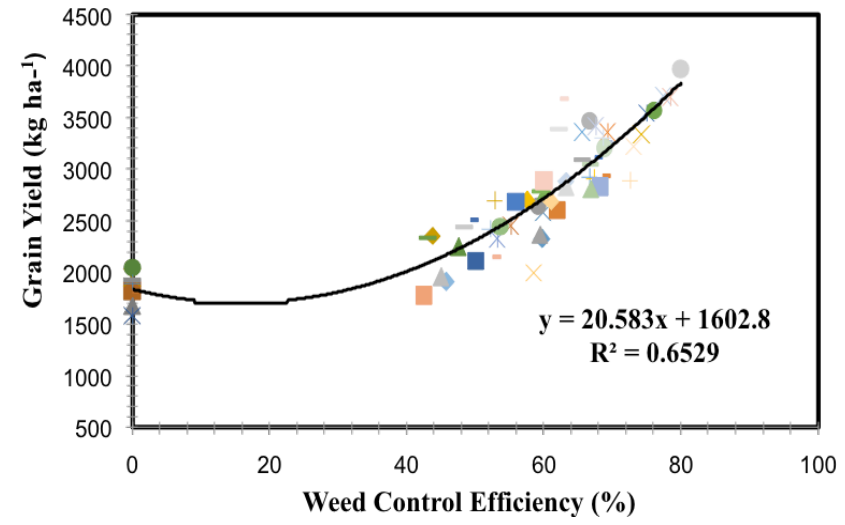

Figure 3: Relationship between grain yield and weed control efficiency.

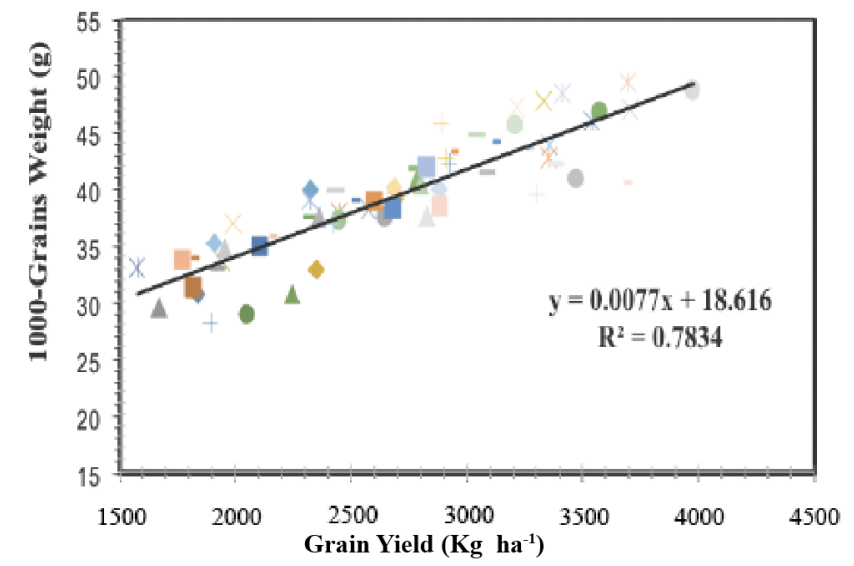

Figure 4: Relationship between 1000-grain weight and grain yield. 
Table 4: Partial Budgeting, Weed Management by Sorghum Green Manure and Different Weed Control Methods in Wheat. Grain Yield Value, PKRs. $=31.25 \mathrm{~kg}^{-1}$

\begin{tabular}{|c|c|c|c|c|c|c|c|}
\hline \multirow{2}{*}{ Particulars } & \multicolumn{7}{|c|}{ Sorghum Green Manuring } \\
\hline & $\mathrm{WCM}_{1}$ & $\mathrm{WCM}_{2}$ & $\mathbf{W C M}_{3}$ & $\mathrm{WCM}_{4}$ & $\mathrm{WCM}_{5}$ & $\mathbf{W C M}_{6}$ & $\mathrm{WCM}_{7}$ \\
\hline $\begin{array}{l}\text { Average Yield } \\
\left(\mathrm{Kg} \mathrm{ha}^{-1}\right)\end{array}$ & 1855.9 & 2555.4 & 3481.6 & 3393.9 & 2252.8 & 3791.5 & 3279.3 \\
\hline $\begin{array}{l}\text { Adjusted Yield } \\
\left(\mathrm{Kg} \mathrm{ha}^{-1}\right)\end{array}$ & 1670.4 & 2299.9 & 3133.5 & 3054.6 & 2027.6 & 3412.4 & 2951.4 \\
\hline $\begin{array}{l}\text { Gross Field Benefit } \\
\left(\text { PRs ha }{ }^{-1}\right)\end{array}$ & 52200 & 71871 & 97921 & 95456 & 63362 & 106637 & 92231 \\
\hline Cost of Herbicides & 0 & 0 & 1400 & 940 & 0 & 1400 & 940 \\
\hline $\begin{array}{l}\text { Cost of Herbicides } \\
\text { Application }\end{array}$ & 0 & 0 & 1520 & 1520 & 0 & 1520 & 1520 \\
\hline $\begin{array}{c}\text { Cost of Labor of Hand } \\
\text { Hoeing }\end{array}$ & 0 & 3600 & 0 & 0 & 0 & 0 & 0 \\
\hline $\begin{array}{l}\text { Cost of Labor for } \\
\text { Tharphali Application }\end{array}$ & 0 & 0 & 0 & 0 & 4000 & 4000 & 4000 \\
\hline $\begin{array}{l}\text { Total Cost that Vary } \\
\left(\text { PRs ha }{ }^{-1}\right)\end{array}$ & 0 & 3600 & 2920 & 2460 & 4000 & 6920 & 6460 \\
\hline Net Benefit (PRs ha $\left.{ }^{-1}\right)$ & 52200 & 68271 & 95001 & 92996 & 59362 & 99717 & 85771 \\
\hline
\end{tabular}

During the experimentation the grain yield of wheat was significantly influenced by the main effect of green manuring. The maximum grain yield of $2944.3 \mathrm{~kg} \mathrm{ha}^{-1}$ was recorded in the case of sorghum green manure followed by sesbania green manure which produce grain yield of $2735.9 \mathrm{~kg} \mathrm{ha}^{-1}$. The minimum grain yield of $2381.6 \mathrm{~kg} \mathrm{ha}^{-1}$ was noted in green manure free plot.

Similarly, all the weed control methods indicated statistically significant differences in the grain yield of wheat. The highest grain yield of $3208.5 \mathrm{~kg} \mathrm{ha}^{-1}$ was achieved in $\mathrm{WCM}_{6}$ (buctril super @ $750 \mathrm{ml} \mathrm{ha}^{-1}+$ tharphali) followed by $\mathrm{WCM}_{7}$ (isoproturon @ $1.00 \mathrm{~kg}$ a.i. $\mathrm{ha}^{-1}+$ tharphali) the acquired grain yield of $3199.8 \mathrm{~kg}$ $\mathrm{ha}^{-1}$. The lone application of buctril super $\left(\mathrm{WCM}_{3}\right)$ and isoproturon $\left(\mathrm{WCM}_{4}\right)$ also performed better to enhancing the grain yield of wheat, both was statistically similar, but they were significantly differed from the rest of weed control methods. The lowest grain yield of $1835.3 \mathrm{~kg} \mathrm{ha}^{-1}$ was noted in the weedy check plots $\left(\mathrm{WCM}_{1}\right)$.

The highest grain yield may be due to the suppression of weed by the allelopathic potential of sorghum at the initial stages of wheat growth with the consequences of less weed-crop competition for nutrient and soil moisture. These findings are supported by the study of Cheema and Khaliq [32] who stated that the incorporation of sorghum fresh residue significantly enhanced the grain yield of wheat. The results are consistent with the work of Amare et al. [19] who documented that increases in grain yield with the application of isoproturon for weed management. The results are also correlated with the finding of Khalil et al. [34] who reported that the application of buctril super significantly increased the grain yield of wheat. Similar results are documented by Malik et al. [35] and Jabran et al. [25], they concluded that grain yield of wheat considerably increased by the application of bromoxynil + MCPA.

\section{ECONOMIC ANALYSIS}

The partial budgeting and marginal analysis of different weed control methods under sorghum green manure practices were performed as suggested by CIMMYT [36] given in Table $\mathbf{4}$ and graphically shown in Figure 5, respectively. The maximum net benefit of PKRs. 99717 was obtained from plots where buctril super @ $750 \mathrm{ml} \mathrm{ha}^{-1}$ along with tharphali $\left(\mathrm{WCM}_{6}\right)$ was

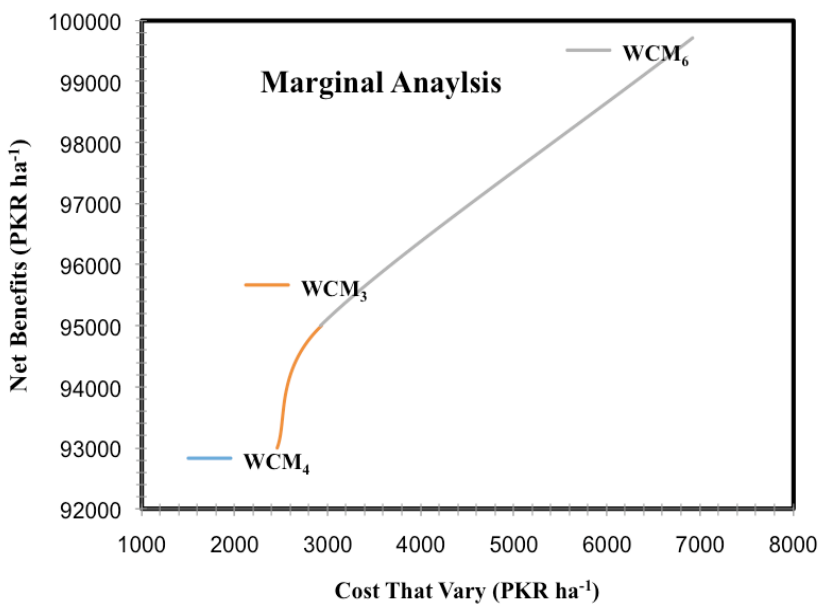

Figure 5: Marginal analysis of different weed control method under sorghum green manure practices in wheat. 
applied while; the minimum net benefit of PKRs. 52200 was achieved from weedy check plots $\left(\mathrm{WCM}_{1}\right)$ in case of sorghum green manure.

\section{CONCLUSION}

It may be concluded that the incorporation of sorghum green manure and the use of herbicides were proven to be economically and ecological safe weed management strategy in rain-fed wheat. The integration of summer green manure with post emergence herbicides significantly reduced weed density and biomass and ultimately increased the yield of wheat. The sesbania green manure incorporation enriched the nutrients of soil for following cash crop but not significantly retard the germination and biomass of weeds of wheat.

\section{REFERENCES}

[1] Abbas SH, Saleem M, Maqsood M, Mujahid MY, Mahmoodul-Hassan and Saleem R. Weed density and grain yield of wheat as affected by spatial arrangements and weeding techniques under rainfed conditions of Pothowar. Pakistan Journal of Agricultural Science 2009; 46 (4): 242-247.

[2] Bekelle, A. Assessment and management of weeds in wheat in Debark woreda, North Gonder. Unpublished thesis. Haramaya - Ethiopia: 2004

[3] Haramoto ER and Gallandt ER. Brassica cover cropping II. Effect on growth and interference of green bean and redroot pigweed. Weed Science 2005; 53: 702-708. http://dx.doi.org/10.1614/WS-04-163R.1

[4] Akbar N, Ehsanullah KJ and Ali MA. Weed management improves yield and quality of direct seeded rice. Australian Journal of Crop Science 2011; 5: 688-694.

[5] Jabran K, Cheema ZA, Farooq M, Basra SMA, Hussain M and Rehman H. Tank mixing of allelopathic crop water extracts with pendimethalin helps in the management of weeds in canola (Brassica napus L.) field. International Journal of Agricultural Biology 2008; 10: 293-296.

[6] Razzaq A, Cheema ZA, Jabran K, Farooq M, Khaliq A and Haider $G$ et al. Weed management in wheat through combination of allelopathic water extracts with reduced doses of herbicides. Pakistan Journal of Weed Science Research 2010; 16: 247-256.

[7] Rao AN and Nagamani A. Integrated weed management in India-revisited. Indian Journal of Weed Science 2010; 42(3-4): 123-135.

[8] Sanyal D. Introduction to the integrated weed management revisited - symposium paper. Weed Science 2008; 56: 140. http://dx.doi.org/10.1614/00431745(2008)56[140:ITTIWM]2.0.co;2

[9] Maity SK and Mukherjee K. Integrated weed management practices in dry directseeded summer rice (Oryza sativa). Indian Journal of Agricultural Sciences 2009; 79: 976-979.

[10] Sarrantonio M and Gallandt ER. The role of cover crops in North American cropping systems. Journal of Crop Production 2003; 8: 53-73.

http://dx.doi.org/10.1300/J144v08n01 04

[11] Kruidhof HM, Bastiaans L, Kropff MJ. Ecological weed management by cover cropping, effects on weed growth in autumn and weed establishment in spring. Weed Research 2008; 48: 492-502.

http://dx.doi.org/10.1111/j.1365-3180.2008.00665.x
[12] Sharif MM, Cheema ZA and Khaliq A. Reducing herbicide dose in combination with sorghum water extract for weed control in wheat (Triticum aestivum L.). International Journal of Agricultural Biology 2005; 7: 560-563.

[13] Teasdale JR and Mohler CL. The quantitative relationship between weed emergence and the physical properties of mulches. Weed Science 2000; 48: 385-392.

http://dx.doi.org/10.1614/0043-

1745(2000)048[0385:TQRBWE]2.0.CO;2

[14] Cheema ZA, Khaliq A and Muneeb M. Response of wheat and winter weeds to foliar application of different plant water extracts of sorghum. Pakistan Journal of Weed Science Research 2003; 9(1-2): 89-97.

[15] Ashiq NM and Ahmad N. Comparative efficacy of different herbicides against broadleaved weeds in wheat. Pakistan Journal of Weed Science Research 2007; 13(3-4): 149-156.

[16] Bhadoria PBS. Allelopathy a natural way towards weed management. American Journal of Experimental Agriculture 2011; 1: 7-20.

[17] Czarnota MA, Paul RN, Dayan FE, Nimbal Cl and Weston LA. Mode of action, localization of production, chemical nature and activity of Sorgoleone: a potent PSII inhibitor in sorghum spp. Root exudates. Weed Technology 2001; 15: 813-825.

http://dx.doi.org/10.1614/0890037X(2001)015[0813:MOALOP]2.0.CO;2

[18] Zahoor F, Malik MA, Mehmood K, Rasheed M, Ansar R and Hussain $\mathrm{M}$ et al. Optimizing herbicide use in wheat (Triticum aestivum) under rain-fed conditions. African Journal of Agricultural Research 2012; 7(35): 4858-4866. http://dx.doi.org/10.5897/AJAR10.699

[19] Amare T, Sharma JJ and Zewdie K. Effect of weed control methods on weeds and wheat (Triticum aestivum L.) yield. World Journal of Agricultural Research 2014; 2(3): 124-128. http://dx.doi.org/10.12691/wjar-2-3-7

[20] Creamer NG and Baldwin KR. An evaluation of summer cover crops for use in vegetable production systems in north Carolina. Horticultural Science 2000; 35: 600-603.

[21] Hossain MI, Haque ME, Sayre KD, Gupta RK, Talukder SN and Islam MS et al. Herbicidal effect on the growth and yield of wheat. International Journal of Sustainable Crop Production 2009; 4(5): 1-4.

[22] Singh RK, Singh SRK and Gautam US. Weed Control Efficiency of Herbicides in Irrigated Wheat (Triticum aestivum). Indian Research Journal of Extension Education 2013; 13(1): 126-128.

[23] DXT, Tawata S, Khanh TD and Chung IM. Decomposition of allelopathic plants in soil. Journal of Agronomy and Crop Science 2005; 191: 162-171. http://dx.doi.org/10.1111/j.1439-037X.2005.00170.x

[24] Borras L, Slafer GA and Otegui ME. Seed dry weight response to source-sink manipulations in wheat, maize and soybean: a quantitative reappraisal. Field Crop Research 2004; 86: 131-146. http://dx.doi.org/10.1016/j.fcr.2003.08.002

[25] Jabran K, Ali A, Sattar A, Ali Z, Yasin M and Hussain M et al. Cultural, mechanical and chemical weed control in wheat. Crop and Environment 2012; 3: 50-53.

[26] Khaliq A, Cheema ZA, Mukhtar MA and Basra SMA. Evaluation of sorghum (Sorghum bicolor) water extract for weed control in soybean. International Journal Agricultural Biology 1999; 1: 23-26.

[27] Caamal-Maldonado JA, Jimenez-Osornio JJ, TorresBarragan A and Anaya AL. The use of allelopathic legume cover and mulch species for weed control in cropping systems. Agronomy Journal 2001; 93: 27-36. http://dx.doi.org/10.2134/agronj2001.93127x

[28] Hartwig NL and Ammon HU. Cover crops and living mulches. Weed Science 2002; 50: 688-699. 
http://dx.doi.org/10.1614/00431745(2002)050[0688:AIACCA]2.0.CO;2

[29] Ahmad SA, Cheema ZA and Ahmad R. Evaluation of sorgaab as natural weed inhibitor in maize. Journal of Plant and Animal Science 2000; 10: 141-146.

[30] Iqbal M. Efficacy of herbicides and row spacing on weeds and yield and yield components of wheat. Sarhad Journal of Agriculture 2003; 1: 23-41.

[31] Awan FA, Rasheed M, Ashraf M and Khurshid MY. Efficacy of Brasica, Sorghum and Sunflower aqueous extracts to control wheat weeds under rainfed conditions of Pothwar, Pakistan. The Journal of Animal and Plant Sciences 2012; 22(3): 715-721.

[32] Cheema ZA and Khaliq A. Use of sorghum allelopathic properties to control weeds in irrigated wheat in a semi-arid region of Punjab. Agriculture, Ecosystems and Environment 2000; 79: 105-112.

http://dx.doi.org/10.1016/S0167-8809(99)00140-1
[33] Mushtaq MN, Cheema ZA, Khaliq A and Naveed MR. A 75\% Reduction in herbicide use through integration with Sorghum+sunflower extracts for weed management in wheat. Journal of Scientific Food and Agriculture 2010; 90: 1897-1904.

http://dx.doi.org/10.1002/jsfa.4159

[34] Khalil MF, Hassan G, Ahmad G and Shah NH. Individual and combined effect of different herbicides on weed control in wheat. Pakistan Journal of Weed Science Research 2008; 14(3-4): 131-139.

[35] Malik MA, Zahoor F, Anser MR, Rasheed M, Aslam U and Mehmood $\mathrm{K}$ et al. Weed biomass and economic yield of wheat (Triticum aestivum) as influenced by chemical weed control under rainfed conditions. African Journal of Biotechnology 2012; 11(7): 1567-1573.

[36] CIMMYT. From Agronomic data to farmer recommendations: An economics training manual. Completely revised edition. Department of Finance: Mexico 1988.

DOI: http://dx.doi.org/10.15377/2409-9813.2015.02.02.3

(c) 2015 Khan et al.; Avanti Publishers.

This is an open access article licensed under the terms of the Creative Commons Attribution Non-Commercial License (http://creativecommons.org/licenses/by-nc/3.0/) which permits unrestricted, non-commercial use, distribution and reproduction in any medium, provided the work is properly cited. 


\section{University Library}

\section{- M M I N E R VA \\ A gateway to Melbourne's research publications}

Minerva Access is the Institutional Repository of The University of Melbourne

Author/s:

BRODIE, G;Khan, MJ;Malik, MA;Ansar, M;Quershi, R

Title:

Integrated Weed Management in Wheat under Subtropical Rain-Fed Conditions

Date:

2015-12-30

Citation:

BRODIE, G., Khan, M. J., Malik, M. A., Ansar, M. \& Quershi, R. (2015). Integrated Weed Management in Wheat under Subtropical Rain-Fed Conditions. Global Journal of Agricultural Innovation, Research \& Development, 2 (2), pp.49-58. https:// doi.org/10.15377/2409-9813.2015.02.02.3.

Persistent Link:

http://hdl.handle.net/11343/58281

License:

Publisher's own licence 